\title{
Effects of the topical application of the extract of Vernonia scorpioides on excisional wounds in mice
}

\author{
P. Dalazen, A. Molon, M.W. Biavatti, M.R.O. Kreuger* \\ Centro de Ciências da Saúde, Universidade do Vale do Itajaí, Caixa Postal 360, Itajaí, \\ Santa Catarina, Brazil
}

\begin{abstract}
Vernonia scorpioides is traditionally widely used in Brazil to treat skin problems, including healing of chronic wounds, such as ulcers of the lower limbs and diabetic wounds. This work investigated the healing process on excisional wounds in the skin of mice, treated daily with an ointment containing $20 \%$ of the ethanol extract of the leaves of Vernonia scorpioides, compared with the control. A skin wound area of about $4 \mathrm{~mm}$ was excised on anaesthetised mice, and after 3, 7 and 14 days of treatment, the lesions were surgically removed and histologically processed. Wound healing activity was determined by the percentage of necrosis area, mononuclear inflammatory cells, fibroblasts and blood vessels. In the acute phase of healing, treatment with piracá extract enlarged the lesions and intensified the necrosis area, compared with the control group. However, the treatment did not inhibit either the recruitment and stimulation of inflammatory cells or the repair process. The results obtained indicate a harmful action of the extract immediately after tissue excision, demonstrated by the increased area of necrotic tissue, clotting and exudates formed in the treated groups. However, the extract did not inhibit the formation of granulation tissue.
\end{abstract}

Keywords: Vernonia scorpioides, wound healing, piracá, erva-de-são-simão.

\section{INTRODUCTION}

Vernonia scorpioides (Lam.) Pers., Asteraceae, popularly known as piracá and erva-de-são-simão, usually grows in poor and deforested soils and is very common in Brazil (Cabreira; Klein, 1980). The topical use of its alcoholic extract is widespread for the treatment of variety of skin disorders including chronic wounds such as ulcers of the lower limbs. Previous studies of the Vernonia crude extract and its derived chloroform and hexane fractions have shown fungicide activity (Freire, 1996), moderate bactericide activity (Campos, 2001) and mild wound healing effects (Leite et al., 2002).

There are an estimated 200 species of Vernonia in Brazil, some of which are traditionally used, such as the fresh, macerated leaves of $V$. condensata, commonly known as Indian Bitterness (fel-de-bugre, fel-de-índio or alumã in Portuguese), which are administered orally to treat gastrointestinal disorders (Monteiro et al., 2001).

On the African continent, other species of Vernonia, such as V. colorata (Cioffi et al., 2004) and V. kotschyana (Nergard et al., 2004). are also traditionally used for healing wounds and skin eruptions.

The genus Vernonia produces characteristic compounds such as sesquiterpene lactones, with several reported biological activities, such as fungistatic (Krishna Kumari et al., 2003), cytotoxic activity (Kuo et al., 2003; Koul et al., 2003) and also acts as a smooth muscle relaxant (Campos et al., 2003). Some other compounds have been isolated from Vernonia, such as flavonoids (Huang et al., 2003), steroids (Tchinda et al., 2003) and polysaccharides
(Nergard et al., 2004). Recent studies focusing on the anti-inflammatory (Mazumder et al., 2003; Iwalewa et al., 2003), antipyretic (Gupta et al., 2003), anticancer (Izevbigie, 2003; Izevbigie et al., 2004; Lambertini et al., 2004 and Howard et al., 2003) and antimalarial (Abosi; Raseroka, 2003; Muregi et al., 2003) activities of several Vernonia species have been published. Also, several papers on the wound healing activity of plant extracts in vivo are already published (Gomez-Beloz et al., 2003; Fujita et al., 2003; Muller et al., 2003; Rashed et al., 2003; Rane; Mengi, 2003).

Thus, the aim of this work is to contribute to the study of the effects of $V$. scorpioides extract in the outgrowth of skin wounds. The new tissue formation and growth in excisional wounds in mice was microscopically evaluated, after the application of an ointment containing extract of $V$. scorpioides.

\section{MATERIALS AND METHODS}

\section{Extract preparation}

Fresh leaves (150 g) of the plant were macerated with $500 \mathrm{~mL}$ of ethanol for seven days in the absence of light, following the traditional preparation method (Leite et al., 2002). The ethanol extract obtained was concentrated up to circa 50\%, under vacuum until ethanol content elimination, using a Rotary Vacuum Evaporator.

\section{Ointment preparation}


The ointment was obtained by mixing $20 \%$ of the crude concentrated extract obtained above with solid vaseline and lanoline (1:2). The control lesions were treated with the ointment base, without the crude extract.

\section{Mice}

Male Swiss albino mice weighing 30-40 g (4 animals per group), were kept in individual cages, in standard environmental conditions, with free access to water and standard pellet food. The animals were used after an acclimatization period of 7 days and the experiments were conducted in accordance with the Univali Ethics Committee.

\section{Excision wound model}

The region used was the back of the hind thigh, in order to make interference by the animals difficult. The animals were anaesthetised with Ketamine 2\% (König Laboratories - Brazil) and Xilazine 6\% (Calier Laboratories - Brazil) (Teles et al., 1997) and after shaving both thighs, the skin was excised using a round biopsy incisor (Stiefel Laboratories - USA), to obtain a wound area of about $4 \mathrm{~mm}$. Each animal received two lesions. The left thigh was treated daily with the ointment (enough quantity to cover the entire lesion) containing the extract while the right thigh received the ointment base. Four animals were sacrificed at 3, 7 and 14 days after induction, being anaesthetised and infused through the left ventricle with $0.9 \%$ saline solution and subsequently, with $10 \%$ formalin solution. The lesions were surgically removed and histologically processed, and sections of 5 $\mu \mathrm{m}$ in thickness were stained with Hematoxilin and Eosin (H\&E).

\section{Quantification of the necrosis areas, mononuclear inflammatory cells, fibroblasts and vessels}

A single blind microscopic evaluation of three sets of serial sections from each lesion was carried out. A reticule eyepiece was used to measure the necrosis areas at a magnification of $600 \mathrm{x}$. The mononuclear cells, fibroblasts and blood vessels were determined numerically at a magnification of $100 \mathrm{x}$ using an optical microscope. The averages of three sets were determined.

\section{Statistical analysis}

Significant differences in the area of necrosis and the quantification of cells and vessels were compared using analysis of variance (ANOVA). The level of significance was determined at $\mathrm{p}<0.05$ for all experiments.

\section{RESULTS}

The effects of Vernonia scorpioides extract on the outgrowth of skin wounds were determined by observing the development of the lesions after 3, 7 and 14 days of treatment with the ointment. The microscopical analysis revealed that treated wounds became worse in the early stage of wound healing, when compared with the control. The lesions treated with the ointment presented enlarged damaged areas when compared with control lesions up to 7 days of daily application. During this period, the treated lesions presented more erythrocytes let out the vessels, a denser crust and clotting (Figure $1 \mathrm{~A}$ ).

The control lesions did not shown any necrosis, crust or clotting, and presented normal formation of granulation tissue, and regeneration of the epidermis at around 7 days (Figures 1 B).

No necrosis area or crust was observed in the treated lesions after 14 days. However, the formation of more immature, granulation tissue was observed and the epidermis was regenerated (Figure $2 \mathrm{~A}$ ). At that same time, the control lesions showed denser parallel collagen fibbers and a thick epidermis (Figure 2 B).

The ointment containing Vernonia scorpioides extract at a concentration of $20 \%$, produced a necrosis area in the acute phase of inflammation in skin wounds in mice (Figure 3$)$, not observed in the control group $(\mathrm{p}<0.05)$. However, this concentration did not inhibit the influx of mononuclear leukocytes, the proliferation of fibroblasts or the formation of blood vessels, in comparison with the control. On determining the percentage, the number of mononuclear cells in the treated groups was around $45 \%$ higher after 7 and 14 days, compared with the treated lesions, where the number of cells was 35\% (Figure 4). The percentage of fibroblasts were higher in the control groups, while at the same time, the average for these cells was $15 \%$ in the treated lesions and $10 \%$ in the control lesions (Figure 5). The number of blood vessels was significantly elevated $(\mathrm{p}<0.05)$ in the control groups after 7 days at a percentage of 7 blood vessels per analysed area, compared with the treated lesions, where around 3 blood vessels per area were found (Figure 6).

\section{DISCUSSION}

The application of an ointment containing Vernonia scorpioides crude extract led to a larger damaged area than the control, during the early phase of the inflammation process, although one week later, normal formation of granulation tissue and re-epithelization could be observed, when compared with the control. Cytotoxic activity of Vernonia has been attributed to the sesquiterpene lactones in the stalks and leaves (Krishna Kumari et al., 2003, Kuo et al., 2003). These properties are important against microorganisms or tumour cells, but could be harmful to the healthy tissue. This could explain the extensive area of damage in the initial stage of inflammation of non-infected wounds treated with the crude extract. On the other hand, although new tissue growth was delayed, the extract did not inhibit this 


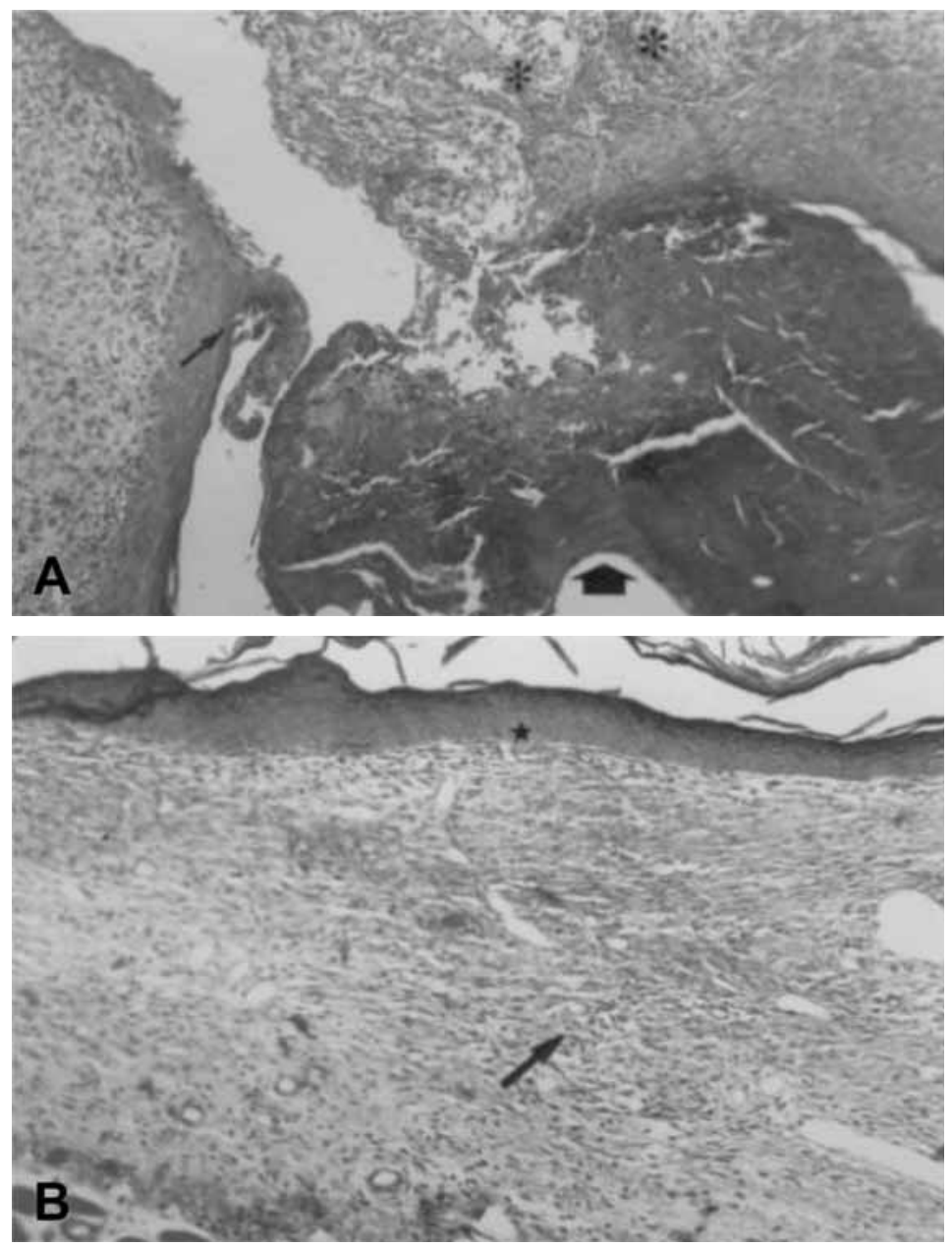

Figures $1 \mathrm{~A}$ and B. Inflammatory reaction 7 days after induction. The area of necrosis is represented by crust, clotting and died cells (small arrow), the interrupted epithelium interrupted (long arrow) and formation of granulation tissue (stars) in treated lesions (A). The control group showed formation of granulation in the area of damage (arrow) and regenerated epithelium (B) (Magnification $x$ 100).

growth, as demonstrated by the increase in fibroblasts and number of blood vessels after 14 days. In guinea pigs, the treatment of skin excisions with ointment containing ethanol extract of Vernonia scorpioides, in the same concentration, did not accelerate the closure time, but improved regeneration and formation of the new tissue after 20 days of treatment (Leite et al., 2002). The same extract has been used to treat of chronic skin ulcers, by elderly people living at the Centro de Convivência para Idosos - CCI), a municipal institution for the elderly, in Itajaí (Santa Catarina, Brazil). Normally, wounds ulcerate because of an inadequate blood supply, providing a point of entry for microorganisms. It is well know that infection and ischemia delays or prevents healing (Magno; Joris, 1996). Although is not possible to affirm Freire et al. (1996) demonstrated the fungicidal activity of $V$. scorpioides and Campos (2001) its moderate bactericide activity, maybe this could explain the traditional use of this extract to treat ulcers of the lower limbs.

The extract of Vernonia scorpioides could also be of benefit against the microorganisms in infected ulcers, contributing to the formation of granulation tissue. It has been demonstrated to be harmful immediately after tissue excision, as observed by the larger area of necrotic tissue, clotting and exudates formed in the treated groups, but the extract did not inhibit the formation of granulation tissue.

\section{ACKNOWLEDGMENTS}

The authors are grateful to Regina Ceris Andreazza, Beatris Souza and Maria Corrêa for their technical support. Financial support was given in the form of grants from the Centro de Ciências da Saúde (Center for Health Sciences) of the University of Vale do Itajaí. 

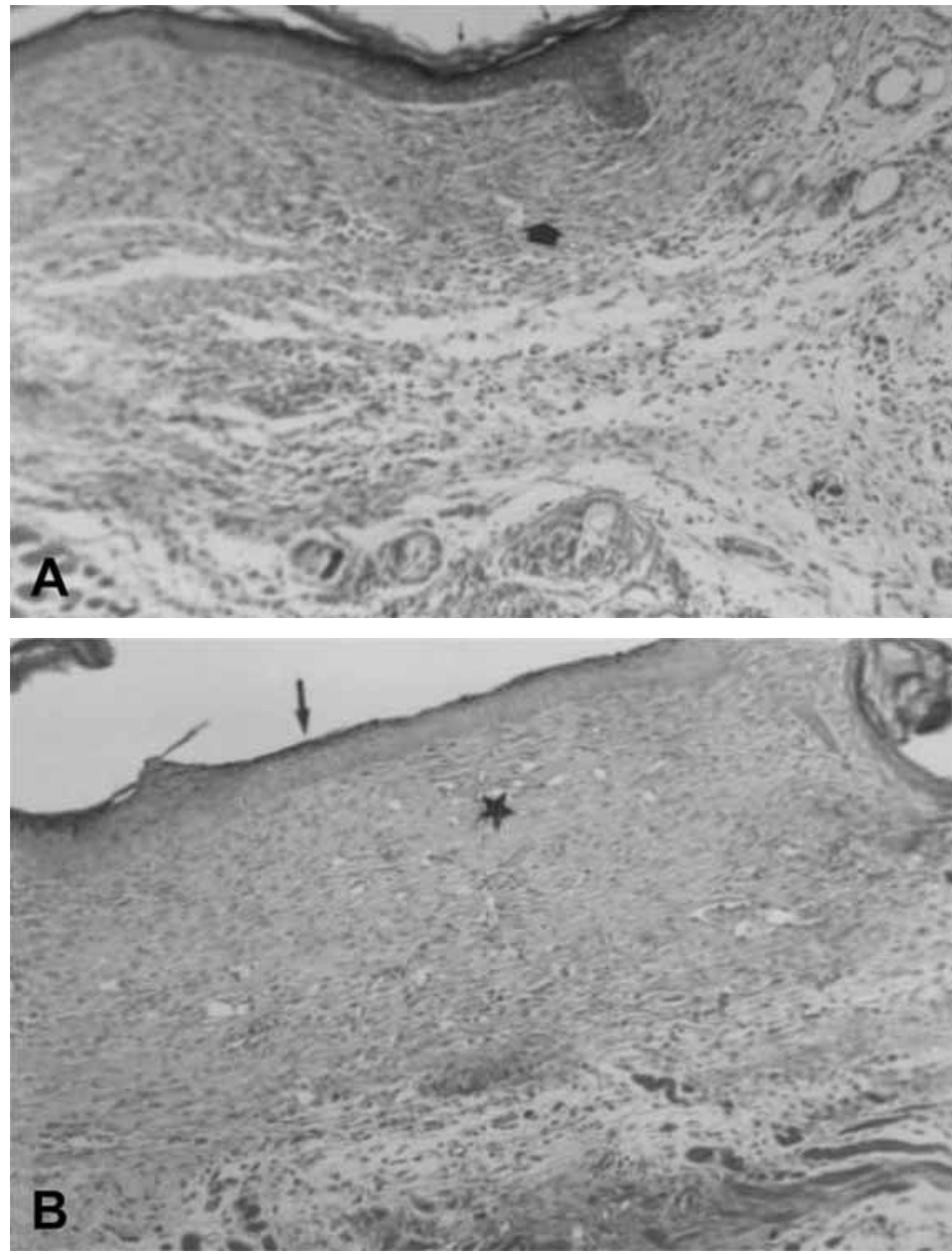

Figures 2 A and B. Inflammatory reaction after 14 days after induction. The treated group showed slight formation of granulation tissue in the area of damage (A) compared with the control group, which showed compact granulation tissue (B) (Magnification $x$ 100).

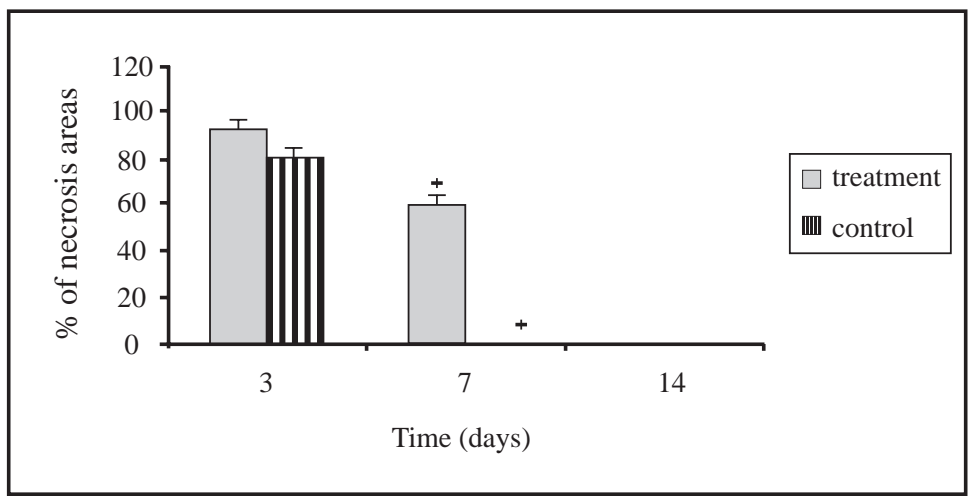

Figure 3. Percentage of necrosis area in control or treated lesions examined 3,7 and 14 days after induction $\left({ }^{*} \mathrm{p}<0.05\right)$. The data corresponds to the mean of the three areas examined at magnification $x 400(n=4)$. 


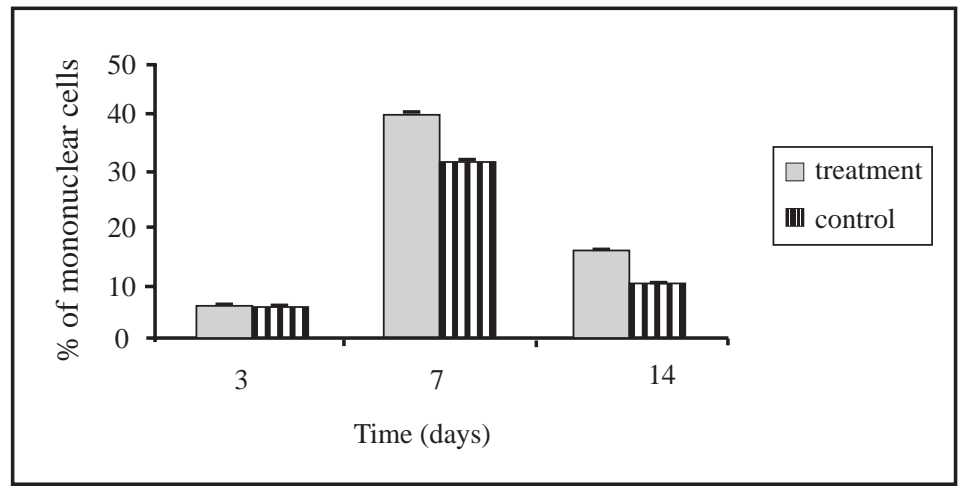

Figure 4. Number of mononuclear cells in the inflamed area investigated in lesions which received or did not receive the extract. Analyses were performed 3, 7 and 14 days after induction. The data corresponds to the mean of three areas examined at magnification x $1000(n=4)$.

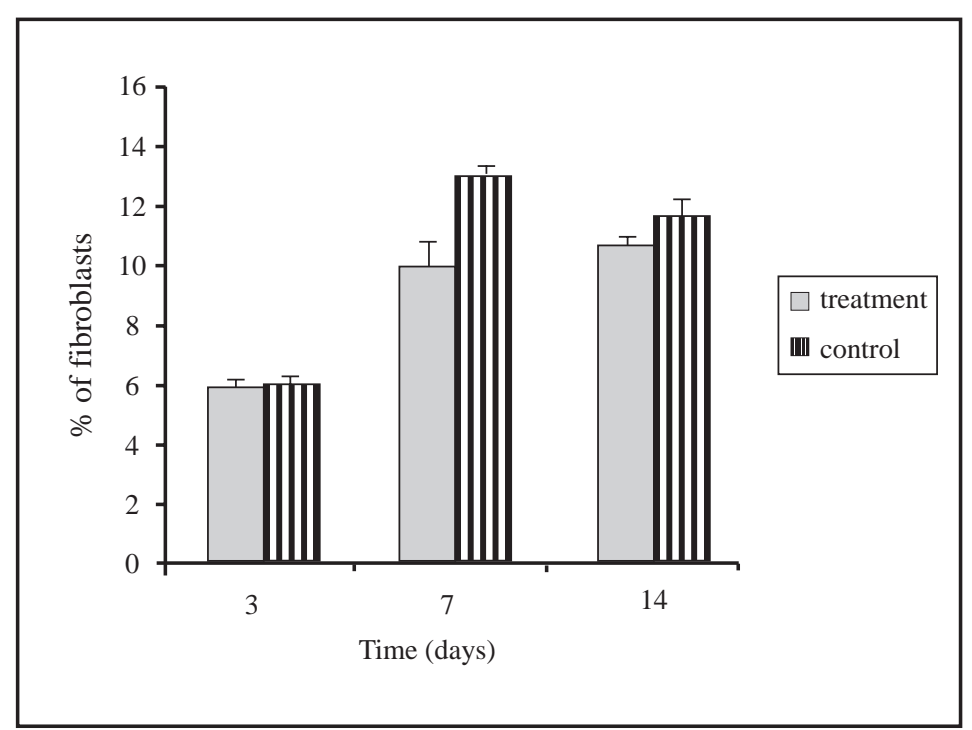

Figure 5. Number of fibroblast cells in the granulation tissue of wounds which received or did not receive treatment. Analyses were performed 3, 7 and 14 days after induction. The data corresponds to the mean of three areas examined at magnification $\times 1000 \quad(n=4)$.

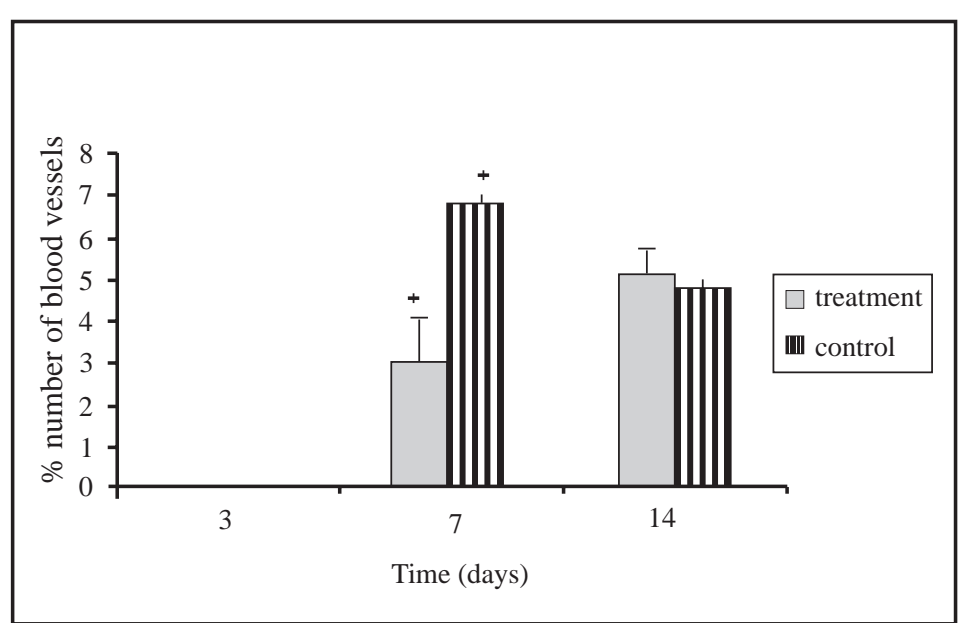

Figure 6. Number of small vessels in the granulation tissue of wounds examined 3, 7 and 14 days after induction $\left({ }^{*} \mathrm{p}<0.05\right)$. The data corresponds to the mean of three areas examined at magnification $x 1000(n=4)$. 


\section{REFERENCES}

Abosi AO, Raseroka BH 2003. In vivo antimalarial activity of Vernonia amygdalina. Br J Biomed Sci 60: 89-91.

Cabrera AL, Klein RM 1980. Compostas: 3. Tribo: Vernoniae. Flora Ilustrada Catarinense 354-355.

Campos M, Oropeza M, Ponce H, Fernandez J, Jimenez-Estrada M, Torres H, Reyes-Chilpa R 2003. Relaxation of uterine and aortic smooth muscle by glaucolides D and E from Vernonia liatroides. Biol Pharm Bull 26: 112-115.

Campos MP 2001. Avaliação da atividade antifúngica e antibacteriana de extratos e frações de Vernonia scorpioides (Lam.) Pers. Monografia Conclusão de Curso. Centro de Educação Superior de Ciências da Saúde. Universidade do Vale do Itajaí.

Cioffi G, Sanogo R, Diallo D, Romussi G, De Tommasi N 2004. New compounds from an extract of Vernonia colorata leaves with anti-inflammatory activity. J Nat Prod 67: 389-394.

Freire MFI, Abreu HS, Cruz LCH, Freire RB 1996. Inhibition of fungal growth by extracts of Vernonia scorpioides (Lam.) Pers. Microbiology 27: 1-6.

Fujita N, Sakaguchi I, Kobayashi H, Ikeda N, Kato Y, Minamino M, Ishii M 2003. An extract of the root of Lithospermun erythrorhison accelerates wound healing in diabetic mice. Biol Pharm Bull 26: 329-335.

Gomez-Beloz A, Rucinski JC, Balick MJ, Tipton C 2003. Double incision wound healing bioassay using Hamelia patens from El Salvador. J Ethnopharmacol 88: 69-73.

Gupta M, Mazumder UK, Manikandan L, Bhattacharya S, Haldar PK, Roy S 2003. Evaluation of antipyretic potential of Vernonia cinerea extract in rats. Phytomedicine 17: 804-806.

Howard CB, Stevens J, Izevbigie EB, Walker A, McDaniel O 2003. Time and dose-dependent modulation of phase 1 and phase 2 gene expression in response to treatment of MCF-7 cells with a natural anti-cancer agent. Cell Mol Biol 49: 1057-1065.

Huang Y, Ding ZH, Liu JK 2003. A new highly oxygenated flavone from Vernonia saligna. Z Naturforsch. C 58: 347-350.

Iwalewa EO, Iwalewa OJ, Adeboye JO 2003. Analgesic, antipyretic, anti-inflammatory effects of methanol, chloroform and ether extracts of Vernonia cinerea less leaf. J Ethnopharmacol 86: 229-234.

Izevbigie EB 2003. Discovery of water-soluble anticancer agents (edotides) from a vegetable found in Benin City, Nigeria. Exp Biol Med 228: 293-298.

Izevbigie EB, Bryant JL, Walker A 2004. A novel natural inhibitor of extracellular signal-regulated kinases and human breast cancer cell growth. Exp Biol Med 229: 163-169.

Krishna Kumari GN, Masilamani S, Ganesh MR, Aravind S, Sridhar SR 2003. Zaluzanin D: a fungistatic sesquiterpene from Vernonia arborea. Fitoterapia 74: 479-482.

Koul JL, Koul S, Singh C, Taneja SC, Shanmugavel M, Kampasi H, Saxena AK, Qazi GN 2003. In vitro cytotoxic elemanolides from Vernonia lasiopus. Planta Med 69: 164-166.

Kuo YH, Kuo YJ, Yu AS, Wu MD, Ong CW, Yang Kuo
LM, Huang JT, Chen CF, Li SY 2003. Two novel sesquiterpene lactones, cytotoxic vernolide-A and -B, from Vernonia cinerea. Chem Pharm Bull 51: 425426.

Lambertini E, Piva R, Khan MT, Lampronti I, Bianchi N, Borgatti M, Gambari R. 2004. Effects of extracts from Bangladeshi medicinal plants on in vitro proliferation of human breast cancer cell lines and expression of estrogen receptor alpha gene. Int J Oncol 24: 419423.

Leite SN, Palhano G, Almeida S, Biavatti MW 2002. Wound healing activity and systemic effects of Vernonia scorpioides extract in guinea pig. Fitoterapia 73: 496-500.

Magno G, Joris I 1996. Cells, tissues and disease: principles of general pathology. England: Blackwell Science.

Mazumder UK, Gupta M, Manikandan L, Bhattacharya S, Haldar PK, Roy S 2003. Evaluation of anti-inflammatory activity of Vernonia cinerea Less. extract in rats. Phytomedicine 10: 185-188.

Monteiro MH, Gomes-Carneiro MR, Felzenszwalb I, Chahoud I, Paumgartten FJ 2001. Toxicological evaluation of a tea from leaves of Vernonia condensata. $J$ Ethnopharmacol 74: 149-157.

Muller MJ, Hollyoak MA, Moaveni Z, Brown TL, Herndon DN, Heggers JP 2003. Retardation of wound healing by silver sulfadiazine is reversed by Aloe vera and nystatin. Burns 29: 834-836.

Muregi FW, Chhabra SC, Njagi EN, Lang'at-Thoruwa CC, Njue WM, Orago AS, Omar SA, Ndiege IO 2003. In vitro antiplasmodial activity of some plants used in Kisii, Kenya against malaria and their chloroquine potentiation effects. J Ethnopharmacol 84: 235-239.

Nergard CS, Diallo D, Michaelsen TE, Malterud KE, Kiyohara H, Matsumoto T, Yamada H, Paulsen BS 2004. Isolation, partial characterisation and immunomodulating activities of polysaccharides from Vernonia kotschyana Sch. Bip. ex Walp. J Ethnopharmacol 91: 141-152.

Rane MM, Mengi SA 2003. Comparative effect of oral administration and topical application of alcoholic extract of Terminalia arjuna bark on incision and excision wounds in rats. Fitoterapia 74: 553-558.

Rashed AN, Afifi FU, Disi AM 2003. Simple evaluation of the wound healing activity of a crude extract of Portulaca oleracea L. (growing in Jordan) in Mus musculus JVI-1. J. Ethnopharmacol 88: 131-136.

Tchinda AT, Tane P, Ayafor JF, Connolly JD 2003. Stigmastane derivatives and isovaleryl sucrose esters from Vernonia guineensis (Asteraceae). Phytochemistry 63: 841-846.

Teles R, Wang CY, Stashenko P 1997. Increased susceptibility of RAG-2 mice to dissemination of endodontic infections. Infect Immun 65: 3781-3787. 